CASSOWARY volume 4 (2) Juni 2021: 119-132

ISSN : :2614-8900

E-ISSN : 2622-6545

Program Pascasarjana Universitas Papua, https://pasca.unipa.ac.id/

\title{
Persepsi, Sikap dan Partisipasi Keluarga Pasien/Pengunjung dalam Menciptakan Kebersihan Lingkungan Rumah Sakit di Kabupaten Manokwari Provinsi Papua Barat
}

\author{
Jumriah $^{1 *}$, Ihwan Tjolli², Eko Agus Martanto ${ }^{2}$ \\ ${ }^{1}$ Pemda Provinsi Papua Barat, \\ ${ }^{2}$ Program Studi S2 Ilmu Lingkungan, Program Pascasarana, Universitas Papua \\ Jalan Gunung Salju Amban, Manokwari, Papua Barat, 98314, Indonesia \\ *Email: unry150182@gmail.com
}

Disubmit: 4 November 2020, direvisi: 31 Maret 2021, diterima: 10 April 2021

Doi: https://doi.org/10.30862/casssowary.cs.v4.i2.60

\begin{abstract}
This study aims to determine the perceptions, attitudes and expectations of the patient /visitor's family in creating a clean hospital environment and to analyze the factors that influence the participation of the patient's or visitor's family in creating a clean hospital environment. The method used in this research is descriptive method with a quantitative approach. The number of samples taken was 19 samples at each hospital, so the total sample of the study was 38 samples. Data collection was done by means of interviews, observation, and documentation. The results showed that most of the visitors' perceptions of the hospital stated that: (1) hygiene problems are things that must be prioritized and are still being improved, (2) the attitude of the visitors is that most of them agree and support all forms of efforts carried out in the context of hygiene management. hospital environment, (c) the level of visitor participation is mostly in the high category related to the cleanliness of the hospital environment. (4) The results of multiple linear regression analysis show that the variables of formal education, counseling, age and length of visit together have an effect on the level of participation in the cleanliness of the hospital environment. The results of the partial relationship test show that formal education and extension variables have a significant effect on the level of participation. The variables of age and length of visit did not affect the level of participation in the cleanliness of the hospital environment.
\end{abstract}

Keywords: Perception, Attitudes, Participation, Environmental Cleanliness, Visitors Hospital

\section{PENDAHULUAN}

Keberadaan rumah sakit di suatu daerah merupakan aspek yang sangat penting. Hal ini terkait dengan fungsi rumah sakit sebagai sarana pelayanan kesehatan yang sangat berpengaruh terhadap kualitas kesehatan masyarakat serta berdampak pada mutu sumberdaya manusia. Kegiatan yang ada di rumah sakit dapat memberikan dampak positif dan negatif. Dampak positif diantaranya meningkatnya derajat kesehatan masyarakat, sedangkan dampak negatif yang mungkin timbul antara lain pencemaran limbah medis dan non medis yang dapat membahayakan bagi kesehatan masya- 
rakat. Limbah yang dihasilkan dari berbagai kegiatan di rumah sakit dapat bersifat racun, infeksius, radioaktif, dan pencemaran lingkungan. Pencemaran lingku-ngan tersebut dapat berupa pencemaran udara, pencemaran air, tanah, pencemaran makanan dan minu-man. Pencemaran lingkungan akibat limbah rumah sakit dapat menimbulkan dampak besar terhadap manusia (Oktavianty, 2016).

Untuk menjaga dan memelihara kondisi ini, bukan hanya tugas pimpinan tapi menjadi tugas semua karyawan rumah sakit termasuk pasien dan pengunjungnya. Dengan demikian akan diperoleh suasana yang nyaman, aman, asri, tentram, bebas dari segala gangguan sehingga dapat memberikan kepuasan pasien dalam membantu proses penyembuhan penyakit. Oleh karena itu peranan manusia sangat penting dalam usaha pencapaian tujuan suatu organisasi. Hal ini dapat dilihat dari segala aktivitas yang dilakukan oleh para karyawan dalam menyelesaikan pekerjaannya.

Rumah sakit yang bersih adalah tempat pelayanan kesehatan yang dirancang, dioperasikan dan dipelihara dengan sangat memerhatikan aspek kebersihan bangunan dan halaman baik fisik, sampah, limbah cair, air bersih, dan serangga/binatang pengganggu. Namun, menciptakan kebersihan di rumah sakit merupakan upaya yang cukup sulit dan bersifat kompleks berhubungan dengan berbagai aspek antara lain budaya/kebiasaan, perilaku masyarakat, kondisi lingkungan, sosial dan teknologi.

Perilaku manusia yang tidak bertanggungjawab terhadap sampah dapat menyebabkan munculnya masalah dan kerusakan lingkungan. Bila perilaku manusia semata-mata mengarah lebih mengarah pada kepentingan pribadinya sendiri, dan kurang atau tidak mempertimbangkan kepentingan umum/kepentingan bersama, maka dapat diprediksi bahwa daya dukung lingkungan alam semakin terkuras habis dan akibatnya kerugian dan kerusakan lingkungan tak dapat dihindarkan lagi (Rizal, 2011). Oleh karena itu, sampah dan benda-benda buangan yang banyak terdapat di lingkungan kehidupan kita perlu ditanggapi secara serius dan perlu dicari cara yang tepat untuk menanggulanginya.

Keberadaan pengunjung dan para pegawai rumah sakit sangat berdampak pada tingkat kebersihannya. Pengunjung atau keluarga pasien yang datang setiap harinya akan meninggalkan sisasisa sampah, terlebih lagi jumlah pengunjung yang datang di tiap harinya tentu berbeda. Misalnya pada akhir pekan ataupun waktu tertentu, pengunjung di rumah sakit umum daerah manokwari lebih ramai dari hari biasanya, hal ini bisa terjadi mengingat masyarakat disibukkan oleh urusan masingmasing. Pada jumlah pengunjung yang semakin ramai maka diharapkan pengunjung memiliki kesadaran akan pentingnya menjaga kebersihan Rumah Sakit Umum Daerah dan dr. Azhar Zahir Kabupaten Manokwari.

Berdasarkan latar belakang maka rumusan masalah adalah bagaimana Analisis Faktor yang mempengaruhi Partisipasi Keluarga Pasien dalam menciptakan kebersihan lingkungan RSUD dan dr. Azhar Zahir, dan yang menjadi tujuan penelitian ini adalah Mengetahui Persepsi, Sikap dan Partisipasi Keluarga Pasien/ Pengunjung dalam menciptakan kebersihan lingkungan RSUD dan dr. Azhar Zahir Kabupaten Manokwari. Menganalisa Faktor yang mempengaruhi Partisipasi Keluarga Pasien dalam menciptakan kebersihan lingkungan RSUD dan dr. Azhar Zahir Kabupaten. 


\section{Usia}

Faktor usia merupakan faktor yang mempengaruhi sikap seseorang terhadap kegiatan-kegiatan kemasyarakatan yang ada. Mereka dari kelompok usia menengah ke atas dengan keterikatan moral kepada nilai dan norma masyarakat yang lebih mantap, cenderung lebih banyak yang berpartisipasi daripada mereka yang dari kelompok usia lainnya.

\section{Pendidikan}

Dikatakan sebagai salah satu syarat mutlak untuk berpartisipasi. Pendidikan dianggap dapat mempengaruhi sikap hidup seseorang terhadap lingkungannya, suatu sikap yang diperlukan bagi peningkatan kesejahteraan seluruh masyarakat.

\section{Lamanya tinggal}

Lamanya seseorang tinggal dalam lingkungan tertentu dan pengalamannya berinteraksi dengan lingkungan tersebut akan berpengaruh pada partisipasi seseorang. Semakin lama ia tinggal dalam lingkungan tertentu, maka rasa memiliki terhadap lingkungan cenderung lebih terlihat dalam partisipasinya yang besar dalam setiap kegiatan lingkungan tersebut.

\section{Penyuluhan}

Menurut Van den Ban dan Hawkins (1999), penyuluhan merupakan keterlibatan seseorang untuk melakukan komunikasi informasi secara sadar dengan tujuan membantu sesamanya memberikan pendapat sehingga bisa membuat keputusan yang benar. Penyuluhan dilakukan dengan berbagai metode, dimana tujuan utamanya menyampaikan informasi kepada sasaran sehingga sasaran menjadi paham, bersikap menyetujui dan menerima. Informasi bidang kebersihan lingkungan selain melalui penyuluhan juhga dilakukan melalui media elektronik, poster maupun pengumuman. Semakin sering seseorang mengikuti penyuluhan dan semakin banyak menerima informasi kesehatan lingkungan dari berbagai sumber maka diduga semakin berpeluang dalam berpartisipasi aktif dalam hal kesbersihan lingkungan.

\section{Kerangka Pemikiran Teoritis}

Kebersihan Rumah Sakit yang dimaksud dalam Penelitian ini adalah kebersihan halaman dan ruangan, yang meliputi fisik, sampah, limbah cair, air bersih, serangga dan binatang pengganggu. Area yang menjadi prioritas dalam mewujudkan Rumah sakit bersih diantaranya adalah halaman, lobby/ ruang tunggu, kantin, toilet, ruang periksa/poliklinik, ruang perawatan, dan Instalasi Gawat Darurat (IGD).

Rumah sakit yang kotor tidak hanya membuat pasien, pengunjung dan karyawan menjadi tidak nyaman, karena menyadari akan menjadi semacam terminal segala sumber penyakit, juga akan menurunkan citra sekaligus mutu pelayanan. Menciptakan kebersihan adalah upaya yang cukup sulit dan bersifat kompleks, sehingga banyak aspek yang menentukan keberhasilan kebersihan di rumah sakit, antara lain budaya/kebiasaan, perilaku masyarakat, kondisi lingkungan, sosial, dan teknologi.

\section{METODE PENELITIAN}

Penelitian ini dilaksanakan pada Rumah Sakit Umum Daerah dan Rumah Sakit dr. Azhar Zahir Kabupaten Manokwari. Metode yang digunakan dalam penelitian ini adalah metode deskriptif dengan pendekatan kuantitatif. Jumlah sampel yang diambil adalah sebanyak 19 sampel pada masingmasing rumah sakit, sehingga total sampel penelitian sebanyak 38 sampel. Pengumpulan data dilakukan dengan 
cara wawancara, observasi dan dokumentasi.

\section{Defenisi Operasional Variabel Persepsi}

Persepsi responden dilihat berdasarkan pendapat/tanggapan mereka terhadap beberapa aspek yang terkait dengan kebersihan rumah sakit, yaitu:

Persepsi : Rumah Sakit Sebagai tempat berobat

Persepsi: Tentang kebersihan rumah sakit

Persepsi : Kontribusi petugas/pegawai dalam kebersihan

Persepsi : Kontribusi pasien/keluarga pasien/pengunjung.

Selanjutnya persepsi dari keseluruhan responden dikelompokkan berdasarkan kesamaan atau kecenderungan kemiripan.

Jumlah skor dari pernyataan pada kuesioner dengan menggunakan skala likert dan setiap pernyataan memiliki skor. Persepsi yang diukur tentang pandangan keluarga pasien/ pengunjung terhadap pedoman rumah bersih tahun 2012 berdasarkan Intruksi Presiden melalui Surat Sekretaris Wakil Presiden Nomor B.1082/Seswapres/KK.04.01 $.10 / 2011$ tanggal 17 Oktober 2011 untuk melaksanakan gerakan indonesia bersih.

\section{Sikap}

Sikap masyarakat diukur berdasarkan sikap/respon responden terhadap beberapa aspek yaitu. Diukur dengan nila skor 3 (setuju), skor 2 (netral), dan skor 1 (tidak setuju). Adapun aspek2 yang disikapi meliputi:

1. Memasang himbauan untuk memelihara lingkungan dan menjaga kebersihan

2. Menyediakan tempat sampah yang mudah dijangkau.
3. Terdapat himbauan menjaga kebersihan dan larangan merokok

4. Terdapat himbauan menjaga kebersihan dan larangan makan pinang/ meludah disembarang tempat.

5. Perlu ada tanaman pot dalam ruangan, kecuali ruangan steril.

6. Menyediakan air bersih yang cukup dan memenuhi syarat

7. Tersedia toilet yang cukup untuk pasien, pengunjung, dan petugas serta berfungsi dengan baik

8. Toilet bersih, tidak berbau, dan kering

9. Tersedia sarana cuci tangan pakai sabun/desinfektan

10. Upaya Menciptakan Pelestarian lingkungan (program penghijauan/ penanaman pohon)

\section{Tingkat Partisipasi}

Tingkat partisipasi keluarga pasien/ pengunjung akan diukur melalui tingkat partisipasi dalam upaya menciptakan rumah sakit bersih berdasarkan Pedoman Rumah Sakit Bersih Tahun 2012. Responden akan diminta memberikan respons atas beberapa aspek. Pengukuran partisipasi dengan menggunakan nilai skor. Selanjutnya juga akan diukur dengan menggunakan skala Likert. Dapat dilihat pada Tabel 1.

\section{Faktor - Faktor yang mempengaruhi} Tingkat Partisipasi (X)

Beberapa faktor yang mempengaruhi tingkat partisipasi masyarakat menurut Pangestu (1995) dalam Ramadyanti (2009) disajikan pada Tabel 2. 
Tabel 1. Kriteria, indikator dan interval tingkat partisipasi

\begin{tabular}{cll}
\hline Skor & Indikator & Interval \\
\hline 3 & Partisipasi responden tinggi & $17-23$ \\
2 & Partisipasi responden sedang & $9-16$ \\
1 & Partisipasi responden rendah & $0-8$ \\
\hline
\end{tabular}

Sumber: Data Sekunder

Tabel 2. Variabel, kategori dan skor faktor - Faktor yang mempengaruhi tingkat partisipasi (X)

\begin{tabular}{|c|c|c|c|}
\hline No & Variabel & Kategori & Skor \\
\hline 1. & Umur & Satuan Tahun. & \\
\hline \multirow[t]{3}{*}{2.} & Tingkat Pendidikan Formal & Tidak Sekolah & 1 \\
\hline & & $\leq \mathrm{SD}$ dan SMP & 2 \\
\hline & & $\begin{array}{l}\text { SMA dan PT } \\
\text { (Perguruan Tinggi) }\end{array}$ & 3 \\
\hline \multirow[t]{3}{*}{3.} & Lama Berkunjung & $\leq 2 \mathrm{jam} / \mathrm{hari}$ & 1 \\
\hline & & $3-6$ & 2 \\
\hline & & $>7 \mathrm{jam}$ & 3 \\
\hline \multirow[t]{7}{*}{4.} & Penyuluhan / Pendidikan Non & Tidak Ada & 1 \\
\hline & Formal (himbauan, stiker, & $1-2$ jenis & 2 \\
\hline & poster, & $\geq 3$ jenis & 3 \\
\hline & $\begin{array}{l}\text { leaflet tentang kebersihan, } \\
\text { larangan }\end{array}$ & & \\
\hline & merokok (Kawasan Tanpa & & \\
\hline & Rokok), CTPS, dilarang & & \\
\hline & $\begin{array}{l}\text { meludah sembarangan, dan } \\
\text { pojok ASI) }\end{array}$ & & \\
\hline
\end{tabular}

Sumber: Data Sekunder

\section{Analisis Data}

Untuk mengetahui pengaruh tingkat pendidikan, penyuluhan/edukasi, umur, dan lama berkunjung terhadap tingkat partisipasi keluarga pasien/ pengunjung dalam menciptakan kebersihan lingkungan Rumah Sakit Kabupaten Manokwari, digunakan analisis Regresi Linier Berganda (linier multiple regression) dengan menggunakan program SPSS versi 24 .

\section{$\mathrm{Y}=\mathrm{b} 0+\mathrm{b} 1 \mathrm{X} 1+\mathrm{b} 2 \mathrm{X} 2+\mathrm{b} 3 \mathrm{X} 3+\mathrm{b} 4 \mathrm{X} 4$}

Keterangan:

$$
\begin{aligned}
\mathrm{Y} & =\text { Tingkat Partisipasi } \\
\mathrm{b} 0 & =\begin{array}{l}
\text { Harga } \mathrm{Y} \text { ketika harga } \mathrm{X}=0 \\
\end{array} \\
\mathrm{~b} 1-3 \mathrm{harga} \text { konstan) } & \text { Koefisien regresi } \\
\mathrm{X} 1= & \text { Pendidikan formal }
\end{aligned}
$$

$\mathrm{X} 2=$ Penyuluhan

$\mathrm{X} 3=$ Umur

X4 = Lama berkunjung

Sebelum dianalisis dengan regresi linier berganda, terlebuh dahulu mengubah data-data ordinal menjadi data interval dengan menggunakan Method of Succesive Interval (MSI). Adapaun penggunaannya memakai SPSS versi 24.

\section{HASIL DAN PEMBAHASAN Tingkat Pendidikan}

Responden dalam penelitian ini adalah masyarakat yang bedomisili di tiga distrik yaitu distrik Manokwari Timur, distrik Manokwari Utara dan distrik Manokwari Selatan. Sebaran jenjang pendidikan terakhir responden dibagi menjadi 4 kelompok yaitu 
tingkat SD, SMP, SMA, dan Perguruan Tinggi seperti yang tertera pada Tabel 3.

Tabel 3. Tingkat pendidikan responden

\begin{tabular}{llll}
\hline No. & Jenjang & f & Persen $(\%)$ \\
& Pendidikan & & \\
\hline 1. & SD & 3 & 7,8 \\
2. & SMP & 5 & 13,15 \\
3. & SMA & 22 & 57,89 \\
4. & Perguruan & 8 & 21,05 \\
& Tinggi & & \\
\hline
\end{tabular}

Total $38 \quad 100$

Sumber: Hasil Pengolahan Data Primer

Berdasarkan Tabel 3 tingkat pendidikan formal responden yang dijadikan sampel menunjukkan bahwa sebagian besar responden memiliki jenjang pendidikan SMA sebesar 50\%. Hal ini mengindikasikan bahwa responden dapat dikatakan sudah relatip terpelajar, sehingga sudah dapat bersikap serta

Pada tabel 4 diatas, terlihat bahwa sebaran usia responden terbanyak pada usia antara 22 - 30 tahun yaitu sebanyak $50 \%$ dan pada usia antara 31 - 40 tahun sebanyak $23.68 \%$. Hal tersebut dapat menunjukkan bahwa sebaran usia responden berada pada usia produktif, dimana pada usia tersebut tentunya responden memiliki pola pikir yang positif tentang masalah sampah dilingkungannya. berperilaku berdasarkan pemahaman mereka terhadap suatu obyek.

\section{Umur}

Usia adalah umur seseorang yang dihitung dari sejak lahir, yang berpengaruh secara langsung terhadap kemampuan fisik, pola berpikir, dan bertindak seseorang. Sebaran responden berdasarkan usia pada penelitian ini terlihat pada Tabel 4 .

Tabel4. Sebaran Responden Berdasarkan Umur

\begin{tabular}{clll}
\hline No & Usia (Tahun) & $\mathrm{f}$ & Persen $(\%)$ \\
\hline 1. & $22-30$ & 19 & 50 \\
2. & $31-40$ & 9 & 23,68 \\
3. & $41-50$ & 5 & 13,16 \\
4. & $51-60$ & 5 & 13,16 \\
\hline \multicolumn{2}{l}{ Total } & $\mathbf{3 8}$ & $\mathbf{1 0 0}$
\end{tabular}

Sumber: Hasil Pengolahan Data Primer

\section{Persepsi Responden terhapap Kebersihan Rumah Sakit}

Persepsi seseorang terhadap kebersihan rumah sakit tentunya sangat bervariasi dan banyak faktor yang melatar-belakangi, diantaranya pemahaman dan wawasan individu tentang permasalahan kebersihan lingkungan rumah sakit. Keadaan persepsi responden terhadap kebersihan lingkungan rumah sakit disajikan pada Tabel 5.

Tabel 5. Sebaran Responden berdasarkan Persepsi bahwa Rumah Sakit sebagai tempat Berobat

\begin{tabular}{llllll}
\hline No. & Persepsi: Rumah Sakit Sebagai tempat & RSUD & \multicolumn{3}{c}{ RSAL } \\
\cline { 3 - 6 } & berobat & Jumlah & Persen & Jumlah & Persen \\
\hline 1 & $\begin{array}{l}\text { Menjaga kebersihan sehingga terbebas } \\
\text { dari penyakit }\end{array}$ & 9 & 0,47 & 7 & 0,36 \\
2 & Membuat pasien/keluarga pasien nyaman & 2 & 0,10 & 4 & 0,21 \\
3 & harus rapih dan tetap bersih & 6 & 0,31 & 8 & 0,42 \\
4 & dokter dan obat harus tersedia & 2 & 0,10 & 0 & 0 \\
\hline
\end{tabular}

Sumber: Hasil Pengolahan Data Primer 
Tabel 5 menunjukkan bahwa sebagian besar (47 \%) responden memiliki persepsi bahwa rumah sakit (RSUD) seharusnya lebih menjaga masalah kebersihan. Hal ini mengindikasikan juga bahwa maslah kebersihan merupakan masalah yang harus diatasi oleh rumah sakit. Sementara responden pada Rumah Sakit Aangkatan Laut (RSAL), sebagian besar responden (42 $\%$ ) memiliki persepsi bahwa kerapihan dan kebersihan harus lebih dipertahankan. Secara umum respon-den memiliki pertimbangan bahwa rumah sakit adalah tempat yang harus nyaman, bersih, rapih agar para pasien merasa aman dan nyaman untuk berobat.

\section{Sebaran Responden berdasarkan Persepsi tentang Kebersihan Rumah Sakit}

Kebersihan dan kerapihan suatu rumah sakit sangat diharapkan oleh pasien maupun keluarga pasien serta para pengunjung. Berbagai upaya telah dilakukan oleh pihak rumah sakit menyangkut kebersihan lingkungan rumah sakit. Pencapaian tingkat kebersihan lingkungan pada tiap rumah sakit rekatif berbeda. Hal ini berkaitan erat dengan berbagai lkendala dan keterbatasan, baik dari sisi anggaran maupun sumberdaya manusia. Keadaan Kebersihan rumah sakit di kabupaten Manokwarfi disajikan pada Tabel 6.

Tabel 6. menunjukkan bahwa persepsi responden terehsdap kebersihan rumah sakit meliputi empat aspek, sehingga kesemua persepsi dapat dikelompokkan. Sebagai misal, sebagian besar $(47.36 \%)$ responden menyatakan bahwa pada RSUD ruangan sudah bersih, namun menyangkut kebersihannya masih perlu ditingkatkan lagi. Sementara pada RSAL sebagian besar responden menyatakan bahwa lingkungannya sudah rapih dan bersih.
Sebaran Responden berdasarkan Persepsi tentang Kontribusi Petugas dalam Kebersihan Rumah Sakit.

Salah satu faktor yang menentukan kebersihan rumah sakit adalah ketersediaan tenaga petugas kebersihan, baik dari segi kuantitas maupun kualitas. Berbagai pandangan, penilaian serta persepsi daripada pengunjung menyangkut sumberdaya manusia atau tenaga petugas kebersihan rumah sakit. Sebaran Responden berdasarkan Persepsi tentang Kontribusi Petugas Kebersihan disajikan pada Tabel 7.

Tabel 7. menunjukkan bahwa baik pada RSAD maupun RSAL sebagian besar responden memiliki persepsi bahwa para petugas kebersihan rumah sakit, yang pokok adalah lebih sadar dalammenjalankan tugasnya. Hal ini mengandung pengertian bahwa faktor kesadaran dan tanggung jawab para petugas adalah faktor penting dalam mewujudkan rumah sakit bersih dan jauh daripencemaran lingkungan.

\section{Sebaran Responden berdasarkan Persepsi tentang Kontribusi Pasien/keluarga Pasien/ pengunjung dalam hal Kebersihan Rumah Sakit}

Selain oleh para petugas kebersihan rumah sakit, peran dan kontribusi para pengunjung juga sangat menentukan kebersihan rumah sakit. Apabila para pengunjung dengan kesadaran yang tinggi untuk menjaga kebersihan, pasti kebersihan rumah sakit juga akan tetap terjaga. Keadaan persepsi tentang kontribusi para pengunjung/keluarga pasien tentang kebersihan rumah sakit disajikan pada Tabel 8. 
Tabel 6. Sebaran Responden berdasarkan Persepsi Kebersihan Rumah Sakit

\begin{tabular}{|c|c|c|c|c|c|}
\hline \multirow[t]{2}{*}{ No } & \multirow{2}{*}{$\begin{array}{c}\text { Persepsi: Tentang kebersihan rumah } \\
\text { sakit }\end{array}$} & \multicolumn{2}{|c|}{ RSUD } & \multicolumn{2}{|c|}{ RSAL } \\
\hline & & Jumlah & Persen & Jumlah & Persen \\
\hline 1 & Masih kurang dan perlu ditingkatkan & 5 & 26,31 & 0 & 0 \\
\hline 2 & sudah cukup tertata dengan baik & 3 & 15,78 & 4 & 21,05 \\
\hline 3 & Ruangan sudah bersih & 9 & 47,36 & 5 & 26,31 \\
\hline 4 & Lingkungannya rapih dan bersih & 2 & 10,52 & 10 & 52,63 \\
\hline
\end{tabular}

Sumber: Hasil Pengolahan Data Primer

Tabel 7. Sebaran Responden berdasarkan Persepsi tentang Kontribusi Petugas Kebersihan

\begin{tabular}{llllll}
\hline No & Persepsi : Kontribusi petugas/pegawai & \multicolumn{2}{c}{ RSUD } & \multicolumn{2}{c}{ RSAL } \\
& \multicolumn{1}{c}{ dalam kebersihan } & Jumlah & Persen & Jumlah & Persen \\
\hline 1 & $\begin{array}{l}\text { Lebih giat lagi dalam menjalankan tugas } \\
\text { kebersihan }\end{array}$ & 4 & 21,05 & 1 & 05,26 \\
2 & $\begin{array}{l}\text { Harus secara sadar menjalankan } \\
\text { tugasnya }\end{array}$ & 7 & 36,84 & 8 & 42,10 \\
3 & $\begin{array}{l}\text { bisa maksimal kalau aturan ditegakkan } \\
\text { tergantung pengawasan dari direktur }\end{array}$ & 6 & 31,57 & 4 & 21,05 \\
\hline
\end{tabular}

Sumber: Hasil Pengolahan Data Primer

Tabel 8. Sebaran Responden berdasarkan Persepsi tentang Kontribusi Pasien/keluarga Pasien/ Pengunjung dalam hal Kebersihan Rumah Sakit

\begin{tabular}{llcccc}
\hline No & Persepsi : Kontribusi pasien/keluarga & \multicolumn{2}{c}{ RSUD } & \multicolumn{2}{c}{ RSAL } \\
& \multicolumn{1}{c}{ pasien/pengunjung } & Jumlah & Persen & Jumlah & Persen \\
\hline 1 & Ikut menjaga kebersihan rumah sakit & 14 & 73,68 & 17 & 89,47 \\
2 & $\begin{array}{l}\text { memberikan masukan/saran kepada } \\
\text { petugas/pihak RS }\end{array}$ & 5 & 26,31 & 2 & 10,52 \\
\hline
\end{tabular}

Sumber: Hasil Pengolahan Data Primer

Tabel 8. menunjukkan bahwa responden pada kedua rumah sakit sebagian besar memiliki persepsi yang sama bahwa betapa pentingnya menjaga kebersihan rumah sakit. Bahkan sebagian kecil diantaranya dapat memberikan masukan/saran kepada pihak manajemen/ petugas rumah sakit menyangkut kebersihan dan kerapihan. Hal ini mengindikasikan bahwa peran para pengunjung dalam bertanggung jawab terhadap kebersihan rumah sakit sudah mulai terlihat.

\section{Sebaran Responden Berdasarkan Sikap Tentang Kebersihan Rumah Sakit}

Berbagai upaya dilakukan dan diupayakan oleh pihak rumah sakit dalam menata dan menjaga kebersihan lingkungan rumah sakit. Namun demikian, hasil yang diperoleh sejauh ini belumlah memuaskan. Harapan yang diidamkan sebuah rumah sakit yang bersih, asri dan terbebas dari sampah, baik di ruangannya maupun dilingkungan rumah sakit. Sebaran responden berdasarkan sikap terhadap kebersihan rumah sakit disajikan pada Tabel 9. 
Tabel 9. Sebaran Responden Berdasarkan Sikap Tentang Kebersihan Rumah Sakit

\begin{tabular}{|c|c|c|c|c|}
\hline No. & Sikap & Setuju & Netral & $\begin{array}{l}\text { Tidak } \\
\text { setuju }\end{array}$ \\
\hline 1 & $\begin{array}{l}\text { Memasang himbauan untuk memelihara lingkungan } \\
\text { dan menjaga kebersihan }\end{array}$ & 38 & 0 & 0 \\
\hline 2 & Menyediakan tempat sampah yang mudah dijangkau. & 38 & 0 & 0 \\
\hline 3 & $\begin{array}{l}\text { Terdapat himbauan menjaga kebersihan dan larangan } \\
\text { merokok }\end{array}$ & 34 & 3 & 1 \\
\hline 4 & $\begin{array}{l}\text { Terdapat himbauan menjaga kebersihan dan larangan } \\
\text { makan pinang/meludah disembarang tempat }\end{array}$ & 36 & 2 & 0 \\
\hline 5 & $\begin{array}{l}\text { Perlu ada tanaman pot dalam ruangan, kecuali } \\
\text { ruangan steril. }\end{array}$ & 37 & 1 & 0 \\
\hline 6 & $\begin{array}{l}\text { Menyediakan air bersih yang cukup dan memenuhi } \\
\text { syarat }\end{array}$ & 38 & 0 & 0 \\
\hline 7 & $\begin{array}{l}\text { Tersedia toilet yang cukup untuk pasien, pengunjung, } \\
\text { dan petugas serta berfungsi dengan baik }\end{array}$ & 38 & 0 & 0 \\
\hline 8 & Toilet bersih, tidak berbau, dan kering & 38 & 0 & 0 \\
\hline 9 & Tersedia sarana cuci tangan pakai sabun/desinfektan. & 38 & 0 & 0 \\
\hline 10 & $\begin{array}{l}\text { Upaya Menciptakan Pelestarian lingkungan } \\
\text { Program penghijauan/penanaman pohon. }\end{array}$ & 38 & 0 & 0 \\
\hline
\end{tabular}

Sumber: Hasil Pengolahan Data Primer

Tabel 9. menunjukkan bahwa secara umum seluruh responden bersikap positip dan setuju dengan berbagai aspek yang terkait dengan pengelolaan kebersihan rumah sakit. Hal ini menunjukkan bahwa dukungan secara luas datang dari masyatrakat untuk menjaga kebersihan lingkungan rumah sakit. Artinya bahwa sebagaimana fungsinya sebagai tempat berobat dan beristirahat sudah semestinya masalah kebersihan lingkungan harus mendapat perhatian serius.

\section{Tingkat Partiasipasi Pengunjung dalam Kebersihan Rumah Sakit}

Berdasarkan persepsi dan sikap para pengunjung maka secara langsung maupun tidak langsung berdampak terhadap partisipasi dalam kebersihan lingkungan rumah sakit. Sebaran responden berdasarkan partisipasi terhadap kebersihan lingkungan dapat ditinjau pada beberapa aspek, seperti disajikan pada Tabel 10.
Tabel 10. menunjukkan bahwa tingkat partisipasi sebagian besar pengunjung berada pada kategori tinggi hampir pada semua aspek, kecuali pada aspek upaya Gerakan kebersihan dan Upaya Promosi Kesehatan berada pada kategori sedang, yaitu masing-masing sebesar $73 \%$ dan $78 \%$ responden. Berdasarkan angka-angka persentase pada masing-masing aspek tersebut terlihat bahwa responden kurang berpartisipasi pada aspek-aspek yang masih bersifat himbauan ataupun gerakan. Dengan perkataan lain bahwa responden sudah paham permasalahannya dalam hal kebersihan lingkungan rumah sakit, sehingga solusinya juga sudah jelas. Sebagai missal permasalahan fisik bangunan, sampah dan air bersih adalah masalah klasik dari tahun ke tahun sehingga diperlukan komitmen bersama.

Keseluruhan aspek kebersihan lingkungan selanjutnya dijumlahkan berdasarkan nilai skor yang dikategorikan atas tingkat partisipasi tinggi, 
partisipasi sedang dan partisipasi rendah separti pada Tabel 11 .

Tabel 11. menunjukkan banhwa tingkat partisipasi responden dalam kebersihan rumah sakit sebagian besar $(73.68 \%)$ berada pada kategori tinggi. Tingginya partisipasi responden ini sangat erat hubungannya dengan keinginan masyarakat pada umum tentang harapan adanya rumah sakit representtative, bersih dan bebas dari sampah. Faktor lainnya adalah bahwa umumnya responden menginginkan rumah sakit yang bersih sehingga sangat termotivasi untuk berpartisipasi langkah-langkah apa saja yang harus dilakukan.

\section{Analisis Faktor-Faktor yang Mempengaruhi Tingkat Partisipasi dalam Kebersihan Rumah Sakit}

Berdasarkan pengolahan data primer, maka untuk mengetahui pengaruh Pendidikan formal (X1), penyuluhan (X2), umur (X3), Lamanya betrkunjung (X4), terhadap tingkat partisipasi Kebersihan Rumah Sakit (Y) maka diperoleh koefisien regresi linier berganda antara variabel bebas dengan variabel terikat disajikan pada Tabel 12 .

Tabel 10. Partiasipasi Pengunjung dalam Kebersihan Rumah Sakit berdasarkan Beberapa Aspek

\begin{tabular}{|c|c|c|c|c|c|c|}
\hline \multirow{2}{*}{ Upaya Partisipasi per Aspek } & \multicolumn{2}{|c|}{ Tinggi } & \multicolumn{2}{|c|}{ Sedang } & \multicolumn{2}{|c|}{ Rendah } \\
\hline & Jumlah & $\%$ & Jumlah & $\%$ & Jumlah & $\%$ \\
\hline $\begin{array}{l}\text { Upaya Menciptakan Kebersihan } \\
\text { Fisik Halaman }\end{array}$ & 20 & 0,52 & 18 & 0,47 & 0 & 0 \\
\hline $\begin{array}{l}\text { Upaya Menciptakan Kebersihan } \\
\text { Fisik Bangunan }\end{array}$ & 32 & 0,84 & 6 & 0,15 & 0 & 0 \\
\hline $\begin{array}{l}\text { Upaya Menciptakan Kebersihan } \\
\text { Toilet dan Kamar Mandi }\end{array}$ & 25 & 0,65 & 9 & 0,23 & 4 & 0,10 \\
\hline $\begin{array}{l}\text { Upaya Menciptakan Penanganan } \\
\text { Sampah }\end{array}$ & 26 & 0,68 & 10 & 0,26 & 2 & 0,05 \\
\hline $\begin{array}{l}\text { Upaya Menciptakan Ketersediaan } \\
\text { Air Bersih }\end{array}$ & 24 & 0,63 & 14 & 0,36 & 0 & 0 \\
\hline $\begin{array}{l}\text { Upaya Menciptakan Pelestarian } \\
\text { lingkungan: }\end{array}$ & 20 & 0,52 & 14 & 0,36 & 4 & 0,10 \\
\hline $\begin{array}{l}\text { Upaya Menciptakan Gerakan } \\
\text { kebersihan }\end{array}$ & 0 & 0 & 28 & 0,73 & 10 & 0,26 \\
\hline $\begin{array}{l}\text { Upaya Menciptakan Promosi } \\
\text { Kesehatan }\end{array}$ & 0 & 0 & 30 & 0,78 & 8 & 0,21 \\
\hline
\end{tabular}

Sumber: Hasil Pengolahan Data Primer

Tabel 11. Partisipasi Pengunjung dalam Kebersihan Rumah Sakit berdasarkan Beberapa Aspek

\begin{tabular}{llcc}
\hline \multirow{2}{*}{ No. } & \multirow{2}{*}{ Nilai Skor Tingkat Partisipasi } & \multicolumn{2}{c}{ Responden } \\
\cline { 3 - 4 } & 17 sampai 23 (Tinggi) & 28 & Persen \\
\hline 1 & 9 sampai 16 (Sedang) & 9 & 73,68 \\
3 & 0 sampai 83 (trendah) & 1 & 23,68 \\
\hline
\end{tabular}

Sumber: Hasil Pengolahan Data Primer 
Tabel 12. Koefisien Regresi Linier Berganda Antara Variabel Bebas DenganVariabel Terikat

\begin{tabular}{lll}
\hline Variabel & Koefisien Regresi & t hitung \\
\hline Pendidikan (X1) & 0,357 & $2,689^{*}$ \\
penyuluhan (X2) & 0,309 & $2,293^{*}$ \\
Umur (X3) & 0,010 & 1,053 \\
Lama berkunjung (X4) & 0,110 & 1,046 \\
\hline
\end{tabular}

Constant $=1,001$, Koef. Determinasi $(\mathrm{R} 2)=0,505$, Koef. Korelasi $(\mathrm{R})=0,711$

$\mathrm{t}$ tabel $(0,05)=2,021, \mathrm{t}$ tabel $(0,01)=2,704$

Keterangan:

* = signifikan pada tingkat kepercayaan $95 \%$

$* *$ = Sangat signifikan pada tingkat kepercayaan $99 \%$

Hasil analisis regresi linear berganda untuk tingkat partisipasi masyarakat dalam Kegiatan Rehabilitasi Hutan dan Lahan diperoleh model persamaan sebagai berikut:

\section{$Y=1,001+0,357 X 1+0,309 X 2+$ $0,010 \times 3+0,110 \times 4$}

Dimana:

$\mathrm{Y} \quad=$ Tingkat Partisipasi

Pengunjung Rumah Sakit

$\mathrm{A}=$ Konstanta

$\beta 1-\beta 3=$ Koefisien Regresi

$\mathrm{X} 1=$ Pendidikam

$\mathrm{X} 2=$ Penyuluhan

$\mathrm{X} 3=$ Umur

$\mathrm{X} 4=$ Lama berkunjung

e $\quad=$ Faktor Galat

Hasil perhitungan analisis korelasi diketahui bahwa korelasi antara variabel $\mathrm{X} 1$ sampai dengan $\mathrm{X} 4$ dengan variabel $Y$ adalah sebesar 0.505. Hal ini menjelaskan bahwa tingkat partisipasi pengunjung terhadap kebersihan rumah sakit di kabupaten Manokwari dipengaruhi oleh keenam karakteristik responden sebesar 50,5\%, dan sisanya sebesar $49.5 \%$ dipengaruhi oleh faktor lainnya di luar model. Menurut Sarwono (2009) koefisien korelasi sebesar 0.505 menunjukkan bahwa korelasi variabel X1 $\mathrm{X} 4$ secara bersamaan dengan variabel $\mathrm{Y}$ termasuk dalam korelasi kuat.

Hasil analisis regresi memperlihatkan bahwa hubungan positif antara tingkat partisipasi pengunjung terhadap kebersihan rumah sakit (Y) terjadi dengan faktor pendidikan (X1), penyuluhan (brosur dll) (X2), Umur (X3) dan Lama berkunjung.

\section{Pengaruh Secara Simultan}

Untuk menguji tingkat keberartian pengaruh variabel bebas secara bersama-sama (simultan) terhadap partisipasi pengunjung dalam kebersihan rumah sakit, dapat dilihat pada analisis varians atau uji statistik F. Analisis varians uji $\mathrm{F}$ disajikan pada Tabel 13.

Tabel 13. Analisis Varians Uji F

\begin{tabular}{lllll}
\hline Sumber variasi & Jumlah Kuadrat & Derajat Bebas & Kuadrat rata-rata & F \\
\hline Regresi & 10,998 & 4 & 2,749 & 8,432 \\
Residual & 10,760 & 33 &, 326 & \\
Total & 21,758 & 37 & & \\
\hline
\end{tabular}

Sumber: Hasil Olahan SPSS 21.0 
Berdasarkan hasil analisis varians uji statistik F, diketahui $\mathrm{F}$ hitung $(8,432)$ lebih besar daripada $\mathrm{F}$ tabel $(0,05 ; 4,33)$ $=2,66$. Semua variabel bebas, yang terdiri dari pendidikan (X1), penyuluhan (X2), Umur (X3) dan Lama berkunjung (X4) secara bersama-sama berpengaruh terhadap tingkat partisipasi pengunjung dalam kebersihan rumah sakit. Hal ini mengandung pengertian bahwa apabila variabel bebas tersebut ditambah atau dikurangi dapat meningkatkan atau menurunkan partisipasi pengunjung dalam hal kebersihan rumah sakit.

\section{Pengaruh Secara Parsial}

Secara parsial pengaruh masingmasing variabel ditunjukkan oleh uji t, seperti pada Tabel 14.

Berdasarkan Tabel 15 hasil uji $\mathrm{t}$ memberikan gambaran bahwa variable tingkat pendidikan formal dan penyuluhan berpengaruh nyata terhadap partisipasi dalam kebersihan rumah sakit; serta variabel umur dan lamanya kunjungan tidak berpengaruh nyata terhadap partisipasi dalam kebersihan rumah sakit.

\section{Pengaruh Pendidikan terhadap Tingkat Partisipasi dalam Kebersihan Rumah Sakit}

Berdasarkan hasil pengujian statistik, nilai $t$ hitung $(2,689)$ lebih besar daripada t tabel $(0,05 ; 4$. 33) $=2,021$. Hal ini berarti bahwa pendidikan formal berpengaruh terhadap tingkat partisipasi dalam kebersihan lingkungan rumah sakit. Dengan tingkat pendidikan yang dimiliki akan berdampak pada pola pikir dan wawasan seseorang sehingga akan mengarahkan seseorang dalam mengambil keputusan. Artinya semakin tinggi tingkat pendidikan seseorang maka cenderung semakin tepat dan benar dalam mengambil keputusan, termasuk didalamnya yang terkait dengan kebersihan lingkungan. Seseorang akan lebih memyadari tentang manfaat penting dari lingkungan sehingga seseorang cenderung untuk berpartisipasi.

\section{Pengaruh Penyuluhan (edukasi) terhadap Tingkat Partisipasi dalam Kebersihan Rumah Sakit}

Berdasarkan hasil pengujian statistik nilai $t$ hitung $(2,293)$ lebih besar daripada $t$ tabel $(0,05 ; 4$. 33) $=2,021$. Hal ini berarti bahwa penyuluhan dan bentuk edukasi lingkungan lainnya yang dimiliki oleh seseorang berpengaruh nyata terhadap tingkat partisipasi dalam kebersihan lingkungan rumah sakit. Semakin sering seseorang mengikuti penyuluhan atau pendidikan formal lainnya yang terkait dengan lingkungan, maka semakin paham tentang permasalahan dan dampak kerusakan/ pencemaran lingkungan. Terlebih lagi menyangkut kebersihan rumah sakit, sebagai tempat yang seharusnya factor kebersihan dan kenyamanan selalu dijaga.

Tabel 14. Hubungan Parsial Variabel Bebas Terhadap Variabel Terikat

\begin{tabular}{llllll}
\hline \multirow{2}{*}{ variabel } & \multirow{2}{*}{ t hitung } & $\mathrm{t}$ table & \multirow{2}{*}{ Peluang } & \multirow{2}{*}{ Keterangan } \\
\cline { 3 - 4 } & & $\alpha 0,05$ & $\alpha 0,01$ & & \\
\hline X1 & 2,689 & 2,021 & 2,704 &, 011 & Signifikan \\
X2 & 2,293 & 2,021 & 2,704 &, 028 & Signifikan \\
X3 & 1,053 & 2,021 & 2,704 &, 300 & Tidak Signifikan \\
X4 & 1,046 & 2,021 & 2,704 & 303 & Tidak Signifikan \\
\hline
\end{tabular}

Sumber: Hasil Olahan SPSS 21.0 
Bentuk penyuluhan yang biasa diikuti seseorang dapat berbentuk ceramah satua arah, dialogis, bentuk poster maupun media cetak dan elektronik lainnya. Berdasarkan hasil pengamatandi lapangan menunjukkan bahwa responden umumnya cukup memahami dan perhatian tentang poster (informasi anjuran kebersihan) yang ditempel di sekitar lingkungan rumah sakit terkait dengan menjaga kebersihan.

\section{Pengaruh Umur terhadap Tingkat Partisipasi dalam Kebersihan Rumah Sakit}

Berdasarkan hasil pengujian statistik nilai $\mathrm{t}$ hitung $(1,053)$ lebih kecil daripada t tabel $(0.05 ; 4$. 33) $=2,021$. Hal ini berarti bahwa variabel umur tidak berpengaruh nyata terhadap tingkat partisipasi dalam kebersihan lingkungan rumah sakit. Dengan perkataan lain bahwa seseorang lebih tua atau sebaliknya lebih berusia muda tidak menentukan partisipasinya dalam hal kebersihan rumah sakit. Perilaku seseorang tentunya terkait erat dengan pemahaman terhadap masalah kebersihan dan dampaknya.

\section{Pengaruh Lama Berkunjung terhadap Tingkat Partisipasi dalam Kebersihan Rumah Sakit}

Berdasarkan hasil pengujian statistik nilai $\mathrm{t}$ hitung $(1,046)$ lebih kecil daripada $t$ tabel $(0,05 ; 4$. 33) $=2,021$. Hal ini berarti bahwa lama berkunjung tidak berpengaruh terhadap tingkat partisipasi seseorang dalam kebersihan lingkungan rumah sakit. Artinya lama tidaknya seseorang berkunjung kerumah sakit tidak berpengaruh terhadap partisipasinya dalam menjaga kebersihan rumah sakit. Hal tersebut juga mengindikasikan bahwa durasi waktu untuk seseorang yang berkunjung ke rumah sakit baik sebagai pasien maupun menjenguk saudara atau kerabat tidak memberikan efek terhadap tingkat partisipasinya dalam hal kebersihan lingkungan rumah sakit.

\section{KESIMPULAN}

Persepsi para pengunjung rumah sakit sebagian besar menyatakan bahwa maslah kebersihan adalah hal yang harus diprioritaskan dan masih terus ditingkatkan. Hal ini tentunya berkaitan dengan meningkatkan kesadaran para petugas dalam menjalankan tanggung jwabnya. Disi lain, kesadaran dan dukukungan para pengunjung/ keluarga pasien diperlukan untuk kebersihan lingkungan rumah sakit. Sikap para pengunjung adalah sebagian besar setuju dan mendukung segala bentuk upaya yang diselenggarakan dalam rangka pengelolaan kebersihan lingkungan rumah sakit. Tingkat partisipasi pengunjung sebagian besar berada pada kategori tinggi terkait dengan kebersihan lingkungan rumah sakit. Hasil analisis regresi linier berganda, menunjukkan bahwa variabel Pendidikan Formal (X1), Penyuluhan (X2), Umur (X3) dan Lama Kunjungan (X4) secara bersama-sama berpengaruh terhadap Tingkat Partisipasi Kebersihan Lingkungan Rumah Sakit (Y). Hasil pengujian hubungan parsial menunjukkan variabel pendidikan formal (X1) dan penyuluhan (X2) berpengaruh nyata terhadap Tingkat Partisipasi Kebersihan Lingkungan Rumah Sakit (Y), sedangkan variabel Umur (X3) dan Lama Kunjungan (X4) tidak berpengaruh terhadap Tingkat Partisipasi Kebersihan Lingkungan Rumah Sakit (Y).

\section{DAFTAR PUSTAKA}

Gerungan, W. A. 2004. Psikologi Sosial. Bandung: PT. Refika Aditama. IKAPI

Oktavianty H. Puspa. 2016. Analisis sistem manajemen lingkungan 
rumah Sakit dalam aspek pengelolaan limbah medis Padat (Studi Kasus Rumah Sakit Umum Daerah Kardinah Kota Tegal). Jurusan Ilmu Kesehatan Masyarakat. Fakultas Ilmu Keolahragaan. Universitas Negeri Semarang.

Peraturan Menteri Kesehatan RI Nomor 159b/MenKes/Per/II/1988 tentang Rumah Sakit.

Rizal, Muhammad. 2011. Analisis Pengelolaan Persampahan Perkotaan. Jurnal Smartek Volume 9 No. 2 Tahun 2011.

Sarwono, Sarlito W., Meinarno, Eko A. 2009. Psikologi Sosial. Jakarta: Salemba Humanika.

Siti Irene Astuti Dwiningrum. 2009. Desentralisasi dan Partisipasi dalam Pendidikan. Yogyakarta: UNY.

Slameto. 1995. Belajar dan Faktor Yang Mempengaruhinya. Jakarta: Rineka Cipta.

Sugihartono, Kartika Nur Fathiyah, Farida Harahap. 2007. Psikologi Pendidikan. Yogyakarta: UNY Press.

Thoha, Miftah. 2003. Perilaku Organisasi Konsep Dasar dan Aplikasi. Jakarta: Rajawali.

Van Den Ban dan Hawkins, H.S., 1999. Penyuluhan Pertanian. Diterjemahkan dari Agricultural Extension oleh Agnes D. Herdianti. Kanisius. Yogyakarta. 